\title{
Intermedijalna korespondencija: A.G.M. - Ljudevit Šestić i Josip Leović
}

ABSTRACT. Mrkonjić Anđelko, Intermedijalna korespondencija: A.G.M. - Ljudevit Šestić i Josip Leović (Intermedial Correspondence: A.G.M. - Ljudevit Šeštić and Josip Leović). „Poznańskie Studia Slawistyczne” 7. Poznań 2014. Publishing House Science and Innovate. pp. 161-174. ISBN 978-83-63795-79-5. ISSN 2084-3011.

The content of the paper examines the intermediate dialogue of the poetic and artistic text on the paradigm of A.G. Matoš's poetry and the painting created by Ljudevit Šestić and Josip Leović. The main thought derives from Miroslav Šincel's ascertainment how the works of Matoš „mirror the most important features of our symbolical-impressionistic modernism”. Šestić's continental landscape impressionist painting and Leović's symbolism in his painting, open therefore the possibility of intermediate style, content and biographical link (Tovarnik, Osijek, Đakovo, Paris, music...), keeping in mind the different positioning on the map of national cultural heritage. And with Matoš's pictorial construction of lyrical text and his artistic sensibility, that is very much possible. In the field of stylistic link, purity of style can be read out, but also stylistic impurities caused by a personal and Homeland fate. This paper is of culturological nature.

Keywords: Antun Gustav Matoš; Ljudevit Šestić; Josip Leović; impressionism; symbolism; intertextuality; intermediacy

\section{Uvod}

Ovaj kulturološki rad u svome okvirnom promišljanju ima misliti postmodernističku teorijsku gestu uspostavljanja granične prohodnosti među elitnom nacionalnom paradigmom (A.G.M.), zatim paradigmom prepoznatoj u svojoj „zakašnjelosti stilskog izričaja”, obrađene i ,uladičene” (Ljudevit Šestić), i onom rubnom, zavičajnom, dovoljno kulturološki 
i kulturno potentnom (Josip Leović) za intermedijalnu korespondenciju, a koja se ovdje uspostavlja na biografskom, sadržajnom i stilskom planu. Naravno, ovako uspostavljena trijadna metodologijska shema sugerira izbjegavanje možebitne manjkavosti postmodernističkoga teorijskog diskursa, a koja se čita kao neka uravnilovka centra/elitnog i ruba/perifernog. Odnosno, stvaranje niza jednakovrijednih - slabih subjekata koji proizvode svoju veliku priču u kojoj je mala priča glavni junak ${ }^{1}$. Dakle, stožernu strategiju pisanja i promišljanja ovog rada nosi nacionalni bard, Antun Gustav Matoš, iz čijeg se segmentiranoga/paradigmatskoga proznog i poetskog opusa uspostavlja književno-likovna poveznička korespondencija s dvojicom slikara koji nemaju takvu poziciju u mapi likovne baštine. Stoga, nije na odmet napomenuti kako je autoru ovog rada prva motivsko-asocijativna pomisao bila prostorna i stilska poveznica. Prostorna je ispisivala slavonsku toponimičnost, mapiranost mjestom rođenja; stilska pak simbolizmom i impresionizmom, s pripadajućim sadržajnim arsenalom tema i motiva. Tako primjerice u radu čitamo motiv vrbe i u različitom mediju, ali i u stilskoj oblikovnosti.

Intermedijalna se korespondencija na relaciji A.G.M. - J. Leović u ovom radu uspostavlja na trima razinama.

\section{Koreografija biografsko-pozitivističkih poveznica}

Započeti tekst rada spominjući pozitivizam te pomišljati na Wilhelma Diltheyja, njemačkog filozofa i povjesničara kulture, a pritom imati na umu status činjenice u sinkronom teorijskom obzoru, može se učiniti anakrono. No valja ipak krenuti od nečega „tvrdog” kako bi ovaj „ples s biografilijama" ovih umjetnika riječi i slike ipak imao siguran i pouzdan oslonac, a teznoj misli rada pripomogao u njenoj razložnoj i utemeljenoj opstojnosti.

${ }^{1}$ Cvjetko Milanja je u razgovoru s Andrijom Tunjićem, među ostalim, iznio svoje mišljenje o postmoderni te je spominjući J.F. Lyotarda i tri njegove velike priče koje su kreirale našu civilizaciju: prosvjetiteljstvo, njemački idealizam i marksizam, kao četvrtu dometnuo postmodernu (cf. Milanja 2013: 4-5). 


\subsection{A.G.M. - ŠSestić - Leović}

Prostorna poveznica ima značiti da su sva trojica rođena u Slavoniji, iako nisu svi svoju poetičku matricu u njoj i realizirali, no o tim će putešestvijima kasnije biti nešto više riječi. Naime, Matoš je rođen u Tovarniku na blagdan sv. Ante 1873. g.; Šestić pak 4. kolovoza 1900. u Đakovu, a Leović u Osijeku, dan uoči Velike Gospe 1885. No sasvim je drugačija slika boravka i daljnjeg života: Matoš se već s dvije godine seli u Zagreb, Šestić se iseljava iz Đakova s nepunih šest godina ${ }^{2}$, dok Leović, izuzev faze školovanja u Beču, cijeli životni vijek provodi u Osijeku.

\subsection{A.G.M. - ŠSestić}

Druga poveznica - Pariz - uključuje Matoša i Šestića, a isključuje Leovića. Pariz je bio iznimno važan, gotovo presudan faktor u trasiranju i formiranju njihovih individualnih poetika, naravno, s različitim rezultatima. Šestić dva puta boravi u ,gradu svjetlosti”, prvi petomjesečni studijski boravak je 1926., a drugi, desetomjesečni, četiri godine kasnije kada se i potpunije upoznaje sa slikarstvom impresionizma, ponajviše Pissarroovim te Sisleyjevim i Monetovim (cf. Peić 1969; Albaneže, 2005). To će iskustvo biti presudno, mogli bismo reći čak sudbonosno, za oblikovanje njegova stilskog izraza koji kritičari obično imenuju „zakašnjelim impresionizmom”, ali ponajveću zaslugu za afirmaciju prešućivanog Šstića ima Matko Peić, koji je govorio povodom Šestićeve smrti da je „Naš pejsaž, naročito sjevernohrvatski riječni pejsaž izgubio u Šestiću jednog od svojih najautentičnijih interpretatora, a hrvatsko slikarstvo umjetnika, koji je svojim kistom držao jednu dragocjenu parcelu u trajno živoj tradiciji: Nikola Mašić - Ferdo Kovačević - Slava Raškaj” (Peić 1969: 191) te da je bio „među onim rijetkim koji su ušli u dušu našeg sjevernog pejsaža" (Albaneže 2005: 218).

2 Primjerice, osnovnu školu pohađa u mnogim mjestima (Ogulin, Otočac, Koprivnica, Ivanec, Brod na Savi, Čakovec), a završava je u Zagrebu godinu prije Matoševe smrti. Tadašnji je isključivi razlog seljakanja očeva (Filip) pravnička služba (kotarski predstojnik), a kasniji, kao akademskog slikara, njegova služba srednjoškolskog profesora po raznim mjestima Hrvatske i BiH-a. 
Matošev petogodišnji boravak (od 1899.) u Parizu te Baudelaireov utjecaj zajedno s ostalim francuskim modernističkim pjesnicama znani su te ih $\mathrm{u}$ ovom radu neće biti posebno naglašavani i/ili reinterpretirani. Nadalje, povezuje ih još jedna umjetnost - glazba - kojom su se u jednom periodu života i prehranjivali. Matoš je svirao čelo, žičani instrument, a Šestić klavir, i to ponajviše u kinu, u vrijeme nijemog filma ${ }^{3}$. Zatim, svojevrsni životni nomadizam, česta promjena mjesta boravka, doduše, motivirana drugačijim razlozima. I bolest (rak grla/glasnica), poslije koje obojica umiru u Zagrebu, Matoš 17. ožujka 1914., a Šestić 12. kolovoza 1962. godine. M. Peić citira Matoševe riječi iz jednog pisma kojima zorno prikazuje to svoje zdravstveno stanje: „Na vratu mi napraviše tri rupe: jednu za cijev za disanje. Vrat mi je silno otekao, morah ležati samo na leđima, hranili su me na cijev kroz nos, dvanaest noći nisam od silnog kašlja trenuo, jer me gnoj i silna sluz, nemogući kroz cijev, nekoliko puta ne zaguši... Životinja ne bi to pretrpjela" (Peić 1969: 207).

Za pretpostaviti je kako je i Šestić proživljavao slične muke kada su mu izvadili glasnice.

\subsection{A.G.M. - Leović}

Poveznica biografske naravi između A.G.M. i Leovića nešto je drugačije prirode. Obojica su boravila u Beču kao studenti. Leović je ne samo završio i usavršio svoje školovanje, nego i trasirao strategiju poetike svoje kiparske, slikarske i grafičke umjetnosti (secesija, simbolizam), za razliku od Matoša koji nije htio postati, kako je sâm znao reći, „konjski dentist”, niti ga je Beč bitno poetički odredio; u tom je smislu njemu Pariz, poznato je, daleko značajniji. Naime, Leović je i svoju prvu umjetničku naobrazbu stekao u Beču, učeći klesarstvo na Obrtno-nastavnoj školi (Gewerbliche Fortbildungsschule) u radionici Eduarda Hausera (1904-1908), a potom je radio kao klesar i kipar u Beču te Grazu i Caransebeşu, i to je prvi njegov boravak u prijestolnici Habsburške Monarhije. Drugi boravak povezan je s periodom nakon školovanja na Privremenoj višoj školi za umjetnost i umjetni

3 Taj je podatak, iako poznat u njegovoj biografiji, autor ovog rada dobio i u razgovoru s čakovečkom obitelji Eldan, koja posjeduje nekoliko njegovih slika i koja je slikara osobno poznavala po toj glazbenoj liniji. 
obrt u Zagrebu kada 1916. odlazi u Beč te studira na specijalnoj grafičkoj školi (K.u.K. Graphische Lehr und Versuchsanstalt) gdje usavršava litografiju. Sljedeće godine vraća se u Hrvatsku, kratko u Zagreb pa u Osijek ${ }^{4}$, gdje će provesti ostatak svoga radnog i životnog vijeka.

No ono što je posebno zanimljivo u ovoj relaciji jest da su se A.G.M. i Leović osobno poznavali, i to za vrijeme Leovićeva studiranja u Zagrebu (1911.-1915.), doznajemo od Danijela Zeca (2013: 33). U njegovu monografskom tekstu (rukopisu) nalazimo i opis Leovića kao studenta: „Leović je u mladosti bio boem, dobro je poznavao književnost, a tijekom studiranja kod Crnčića u Zagrebu prijateljevao je s A.G. Matošem, koji je tada bio bolestan, i pri kraju života" (Zec 2013: 247). Zec je do ovog podatka došao putem povjesničara Ive Mažurana. Tako da na kraju možemo ustvrditi još jednu „slabu” poveznicu - boemski način života, makar manjim dijelom kada je riječ o Leoviću. Iz tog poznanstva, povodom 40 godišnjice Matoševe smrti, proizišao je Matošev portret crtan Leovićevom rukom nastao 1956. godine. Na tom se crtežu kredom nalazi kratak autorov tekst, gdje čitamo da je rađen po sjećanju, četrdeset godina poslije Matoševe smrti. Dakle, Leović je na tom portretu Matošu produžio život za dvije godine.

\section{Motiv vrbe - interdisciplinarna i stilska korespondencija}

Motiv vrbe nalazimo prisutnim kod sve trojice navedenih umjetnika riječi i slike. U Šestićevu je slikarskom opusu on najzastupljeniji, dok je u Matoševu i Leovićevu znatno manje prisutan, ali ne i nebitan. Možda je tomu jedan od razloga što to drvo ponajčešće raste uz vodu, rijeku, baru te je Šestiću, slikaru impresionističkog oka i duše, bio slikarski intrigantan

${ }^{4}$ Za Leovićevu je životnu i umjetničku biografiju jako bitno jedno poznanstvo. Naime, početkom 1920-ih Leović se upoznao s bogatim osječkim industrijalcem Rudolfom Povischilom, koji mu je postao blizak i drag prijatelj, ali prije svega mecena preko kojega dobiva različite likovne narudžbe. Druga napomena tiče se njegova fizičkog i psihičkog profila dobivena iz razgovora (u lipnju 2013.) s potomcima osječkog ortopeda dr. Maroevića. Naime, liječnikova kćerka Dubravka Maroević rekla mi je da je Leović bio hrom na jednu nogu, a kroz probleme s protetikom zbližio se s njenim ocem, ali i to da je bio introvertirana osoba. Možda crnilo u njegovim litografijama ima u supstanciji svog sadržaja svoju simbolističku individualnu podlogu. 
i izazovan. Statično, grbavo i gnomično stablo vrbe ${ }^{5}$, njene nestašne grane i ljupka, staklasta površina vode kraj nje, ponekad kao ogledalo, a ponekad kao treperava površina, gdje titra koloristički raster oblika smještenih uz samu obalu, jednostavno i danas promatrača, onoga neopterećenog zakašnjelošću njegova impresionizma, odmara i osvježava svježinom boravka u prirodi. Stoga ne čudi što je Šestić često slikao pejsaže u kojima motrimo ovo stablo, vrbe su na tim slikama temeljni motivski i kompozicijski element; slikao ih je u svim godišnjim dobima. No o Šestićevu i Matoševu impresionizmu bit će više riječi u trećem poglavlju.

Kod Matoša i Leovića situacija je pak nešto drugačije naravi, i na planu učestalosti tog motiva u njihovim opusima i glede stilske uporabljivosti, koja se mahom ograničava na prispodobivost $\mathrm{i} / \mathrm{ili}$ pripadnost simbolističkom stilskom korpusu. Obojica motiv vrbe uranjaju u noćni ugođaj: tajnovito, sjetno, mračno raspoloženje koje otajstvom individualne duše korespondira s otajstvom prirode, nakrcane simbolima. Svaki svoju korespondentnu aluzivnost izražava svojom formom izraza - riječima/pjesničkim slikama jedan, a drugi grafičkim linijama i tamnim površinama litografske matrice. Povjesničar umjetnosti Zec tako zapisuje: „Leovićeve litografije poetski su pejzaži, u njihovim je malim formatima zgusnut melankolični ugođaj matoševskog rukopisa" (Zec 2013: 246-247). Paradigmatski primjer motiva vrbe u Matoševu poetskom tekstu nalazimo u sonetu Jesenje veče, preciznije - u trećem i četvrtom stihu druge katrene: „kako mrke bivaju / Vrbe, crneći se crnim vranama" (Matoš 1973: 17).

Ovdje svakako imamo na umu da motiv vrbe nije baš u prvom redu njegovih simbolističkih motiva, ali i putem njega možemo jasno detektirati pjesnikovu simbolističku poetiku. Naime, vrba u ovoj pjesmi postaje poetizirani simbol samoće uronjene u hladnu i mokru atmosferu mraka i crnila, a ta crna boja svoje ishodište ima u jednoj od dviju fundamentalnih Matoševih tema - temi smrti. Poetsko oblikovanje te pjesničke slike (stablo vrbe uz rijeku, noć/suton, mnoštvo vrana na granama vrbe, hladnoća) iskazuje iznimnu sadržajnu i izražajnu slojevitost ovoga poetiziranog simbola. On iskazuje egzistencijalnu usamljenost i zebnju, mračnu i nejasnu slutnju

5 Jedno od simboličkih značenja ovog drveta može se pročitati u Rječniku simbola, a glasi: „Kažimo napokon još i to da je to stablo, zbog načina na koji se njegove grane pomiču, slika ljupkosti i otmjenosti oblika" (Chevalier, Gheerbrant 1989: 765). 
kraja ljudskoga horizontalnog trajanja, utonuće svake vertikale, jer ni skriveni ,toranj” (2. stih druge katrene) ni ,jablan” (2. stih 2. tercine) ne mogu pjesničkom subjektu dati ni naduni utjehu. Vrane, pak, samo intenziviraju taj osjećaj u tkivu poetskog organizma, a u supstanciji svog sadržaja unose konotativne semanteme Baudelaireova Gavrana. Na razini izraza, glazbenošću stiha (aliteracija, asonanca i dr.) Matoš i pridjev crn oglagoljuje (glagolski pridjev sadašnji!), zacrnjuje tu samoću/usamljenost i kao da to stanje ljudske duše pretvara u vječnu sadašnjost pjesničkog subjekta.

\section{A.G.M. i Šestić u impresionističkoj vizuri}

Matošev će se impresionizam ${ }^{6}$ u ovom radu promatrati i/ili promišljati samo na jednom paradigmatskom primjeru, pjesmi $U$ travi (u intertekstualnoj korespondenciji s pjesmom Vladimira Vidrića Dva pejsaža/Pejsaž I), a intermedijalna će se veza sa Šestićevim slikarskim impresionizmom detektirati drugačijom metodologijskom strategijom, jer ova stilska odredba obuhvaća njegovu najveću i najznačajniju stvaralačku fazu te će se opservacija njegova slikarskog impresionizma motriti kroz više paradigmi i vizuru sintetičnijeg pogleda.

\subsection{Uvodne napomene o impresionizmu Matoševe pjesme $U$ travi}

Budući da rad apostrofira intermedijalnu osjetljivost književnog i likovnog teksta putem navedene stilske odrednice, a ima namjeru detektirati i dubinsku strukturu paradigmatskih primjera navedenih umjetnika, nije na odmet imati na umu svojevrsni memento impresionističke poetičke matrice, a koji će biti, naravno, inkorporiran u analizi navedene pjesme.

Matoševa pjesma $U$ travi, objavljena 1909., nije antologijska pjesma ovog barda hrvatske lirike, no putem njenog poetskog tkiva moguće je detektirati impresionističku stilsku dionicu pjesnikova književnog rada. Napominjemo dionicu, imajući u vidu da je, kako je to već primijetio Viktor

${ }^{6}$ Bitno je napomenuti u ovom dijelu teksta da je, iako ga u književnopovijesnim raspravama svrstavamo među impresioniste, impresionizam prispodobiv/primjeren samo jednom dijelu Matoševe lirike, a donekle i pripovjednoj prozi (Žmegač 1993: 56). 
Žmegač (1993), Matošu prispodobiv i primjerice simbolizam, a impresionističku poetiku on nije cjelovito izgradio/razvio ${ }^{7}$, no svakako je nalazimo ne samo u njegovu lirskom tekstu, nego i u novelističkom (Kip domovine leta 188*, Nekad bilo - sad se spominjalo), putopisnom, feljtonističkom i kritičarskom.

Svakako treba imati na umu da je priroda/krajolik/pejsaž u doba moderne simbol čovjeka i njegove subjektivnosti ${ }^{8}$ (Amielova krilatica - pejsaž je duševno stanje čovjeka), ona nije iskustvena zbilja, priroda je ,subjektivni estetski projekt”, odnosno ona je ,subjektivna predodžba, simulacrum čovjekove subjektivnosti, njegovih izmaštanih vizija ili kulturnih sjećanja i citata" (Oraić Tolić 2013:67). To Amielovo jedinstvo čovjekove duše i prirode, gdje je priroda paradigma i slobode, nije baš u potpunosti primjenjiva u Matoševu lirskom diskursu. Jer, tada popularna, Amielova maksima, koja pomiruje tradicionalnu opreku čovjeka i prirode, kod Matoša - ne pomiruje - poradi domoljubnih i egzistencijalnih otegotnih razloga (Hrvatska neslobodna, Matoševa izvandomovinska nomadska kalvarija). Dakle, pejsaž kod Matoša nije prostor čistoga estetskog užitka, on je uvijek pod sjenom upitnosti i opstojnosti osobne i domovinske sudbine, a njegova pjesma $U$ travi paradigmatska je konzistencija takvoga recepcijskog obzora. U vedro/ idilično pejsažno tkivo ugođaja impresionističkih poetskih slika Matošev pjesnički subjekt unosi sudbinu svog stradanja i čežnje za domovinom ,tuđinskog moga stradanja” (Matoš 1973: 21).

\subsection{Impresionizam $U$ travi}

Ovu ćemo stilsku odrednicu detektirati u trijadnom odnosu A.G.M. V. Vidrić - Lj. Šestić, s već napomenutim paradigmatskim primjerima. Prvih 12 stihova, od ukupno 20 Matoševe pjesme $U$ travi, nose kompetencije impresionističkoga stilskog izričaja, u narednim četirima pjesnički subjekt unosi onaj resurs semantičkog i ugođajnog repertoara, koji nije baš

7 Žmegač primjećuje kako je Matoš znao biti „u suprotnosti s autentičnim impresionizmom, pogotovo s poetikom mimetičke osjetilnosti i neposrednosti", a koja se napose detektira „u nefikcionalnoj prozi, u putopisima, feljtonima, književnim i likovnim kritikama” (Žmegač 1993: 56).

${ }^{8}$ Matoš je bio upoznat s teorijom krajolika H.F. Amiela i M. Barrèsa, neoromatičarskog buđenja interesa za prirodu u umjetnosti fin de sièclea (Oraić Tolić 2013: 66). 
najprimjereniji prvome modernističkom pravcu u umjetnosti, a završna četiri opet dobivaju impresionističku oznaku, no njihovo uokvirenje čitave/ cijele pjesme čita se promijenjenim tonom i ugođajem impresionističke pjesničke slike. Naime, u tih 12 stihova ugođaj/ozračje, kao jedan od najbitnijih elemenata impresionističkog teksta, svijetao je, vedar, topao i osunčan. Matoš na motivima: vedrog neba, prašnog puta, ševe, „cvijetim žutima”, sela, tornja, vrbika, slavuja i sl. predočuje pejsaž koji nudi odmor za oči urbanom biću, gotovo bukoličku idilu. To je scena prostora koji se gleda - izvana, pjesnički je subjekt promatrač „u travi”, on nije konstitutivni dio toga prirodnog sklopa. Vidrić pak u Pejsažu I daje ugođaj (umirujući), gdje je subjekt/čovjek posredno prisutan („,crveni krovovi”, „podnevno zvono”), zapravo stopljen s podnevnom atmosferom; unutra je svojom integrativnom funkcijom u panteističkoj slici svijeta, indiferentan je glede svoje ruralne ili urbane odrednice, nema ni primisao o ekspresiji neke ljudske čežnje, žudnje, želje, gorčine, za razliku od Matoševa pjesničkog subjekta. Svjetlo kao motiv i kao konstitutivni element impresionističke matrice kod Vidrića je dosljedno provedeno u čitavom prostoru pjesme, a Matoš, otvarajući pjesmu svjetlom i vedrinom, zatvara ju vjetrom, oksimoronskom promjenom nemirnog mira te na taj način resemantizira impresionističke motive (granje, selo, sunce, toranj, vitlanje zrakom osušenog rublja) drugačijom ugođajnom atmosferom. Paradigmatski su primjeri motivi sela i uznojenog čela:

1. selo

6. stih: „Pruža molbu tornja k nebu skrušeno”;

18. stih: „Diže k suncu uzdah tornja skrušeno”.

2. uznojeno čelo

7. stih: „Vjetar hladi uznojeno čelo";

19. stih: „Vjetar hladi umireno čelo”.

Pjesnički je subjekt osoba (flaner) koja šeta, luta, promatra impresionističkom osjetljivošću ${ }^{9}$ mnoštvo vizualnih, auditivnih, taktilnih senzacija u pejsažnom prostoru (,žito šušti”, „kukci zuje među cvijetim žutima”, srebrni vrbik, pjev ševe i slavuja, prašnjavi put i dr.). On uživa u bojama, nijansama, zvukovima, teži dočarati prostorni ugođaj,

${ }^{9} \mathrm{U}$ apercepciji ove osjetilnosti uključujemo i filozofsku podlogu impresionizma austrijskog fizičara i filozofa Ernsta Macha. 
atmosferu, no to jedinstvo subjekta s prirodom samo je prividno, ,jer zbiljski svijet nije ništa drugo nego promjenjiv svijet osjeta" (Žmegač 1993: 17). Impresionistički je subjekt svjestan da je subjektivnost nestalna kategorija, da on percipira tek segmente zbilje dojmom, impresijom, želi ipak tim fluidnim trenucima brzo dati oblik, formu, ali s mišlju kako je upitna čvrstoća te forme, te krhke supstance označena mijenom (u slikarstvu će ta spoznaja dovesti do apstraktnog slikarstva!), stoga on slavi svečanost trenutka, bez dubokoumnih misli o simbolima, smislovima, ontologiji, mistici ili unutarnjoj ekspresivnosti, odnosno prepuštanje impresionističkim dojmovima zapravo znači - ne tražiti uzročne odnose među senzacijama zbilje. Matoševa pjesma toga ima (,žito šušti”, vjetar „vitla rublje sušeno”, „Tamo iza srebrnog vrbika, / Blizu mlina, pjeva slavić ubavi”), no u taj pejsažni dekor Matoš impresionističku ugođajnu sliku onečišćuje aluzijom nesretne sudbine pjesničkog subjekta („mog stradanja”). Ovdje također nalazimo i još jedno obilježje književnog i likovnog impresionizma - prizor iz svakidašnjeg života (sušenje rublja).

Motiv vjetra također je paradigmatski primjer impresionističke poetike. Naime, ako se podsjetimo da je impresionizam nastao i bio „kršten” u Monetovu slikarstvu „Impresijom” te da je u svojem šestogodišnjem trajanju (1874.-1880.) ušao i u druge umjetničke discipline, pa i izvanumjetničke, onda moramo konstatirati da su ti pioniri ovog stila (Pissarro, Sisley, Monet $^{10}$, Renoir i dr.) slikali i one do tada nepoželjne motive: izmaglicu, maglu, dim, vrućinu, i već spomenuti vjetar. Upravo je Šestić, kao ,jedini primjer

${ }^{10}$ Glede Šestićeva zakašnjelog impresionizma, valjalo bi spomenuti da je Clod-Oscar Monet (1840.-1926.) u Parizu započeo slikati 1900. godine svoj ciklus lopoča (nakon što je već višestruko interpretirao isti motiv u različitim kolorističkim, tonskim i svjetlosnim vrijednostima: stogove sijena, katedralu u Rouenu i sl.), a Šestić je tek tada rođen u Đakovu. Šestić svoj slikarski impresionizam počinje razvijati oko godine 1935., stanovito usporavanje razvoja teče tijekom Drugoga svjetskog rata, a poslije 1945. razvio ga je do one razine koja ga mapira u popis nacionalno relevantnih slikara. Svakako, imamo na umu da se tijekom kasnih pedesetih i šezdesetih godina u hrvatskoj likovnoj sceni događaju svjetski relevantne likovne činjenice (Exat 51, Gorgona, Nove tendencije), a Šestičeva je poetika impresionizma miljama daleko od tih likovnih strategija pa su se mogli u zagrebačkom/hrvatskom prostoru o njemu čuti negativni kritički tonovi. Matko Peić zapisuje: „Podržavao sam ga nizom članaka, boreći se protiv onih koji su govorili da je jučer bio briljant, a danas diletant, osobito sam smatrao da ga treba zaštititi u trenutku kada je otvorio 1960. godine u Umjetničkom paviljonu svoju retrospektivnu izložbu" (Peić 1969: 207). 


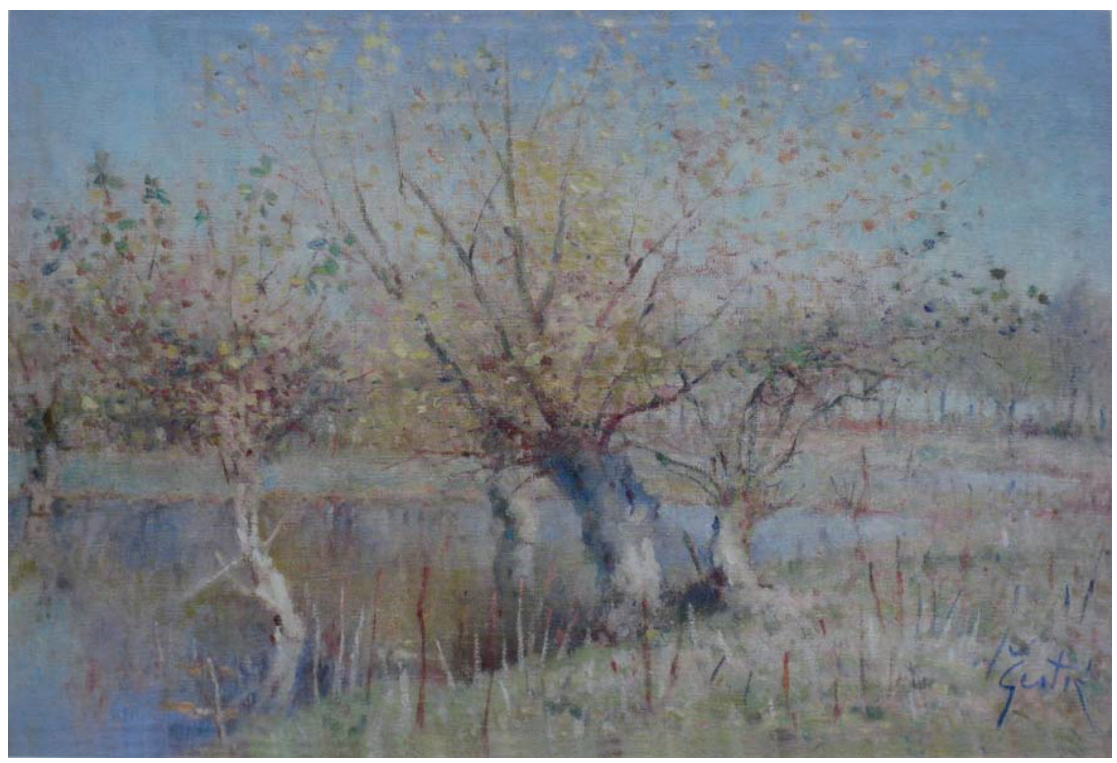

Ljudevit Šestić, Vrbe uz riječni rukavac, ulje na platnu, 1955.

Josip Leović, Portret A.G. Matoša (po sjećanju), ugljen, 1956.

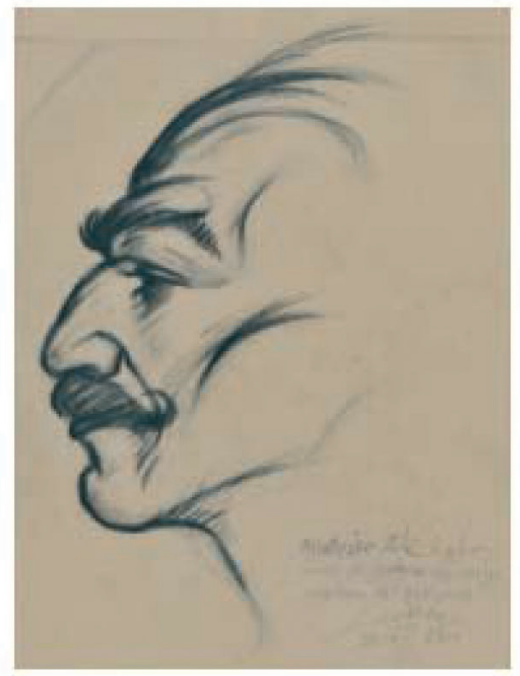




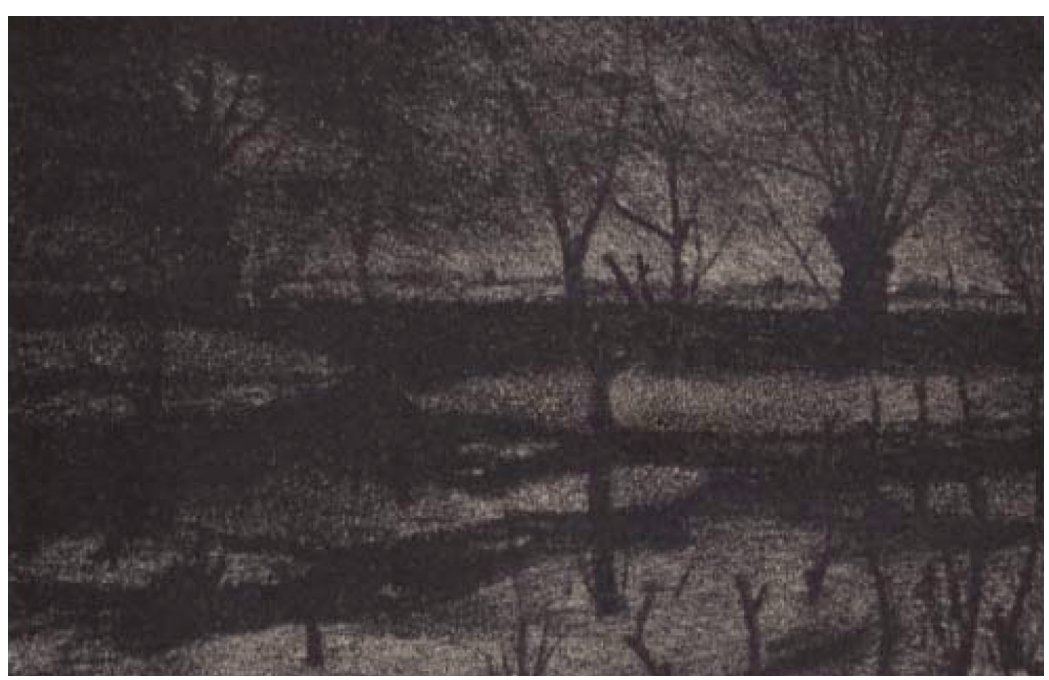

Josip Leović, Iz Tvrđavice, litografija, 1922.-1929.

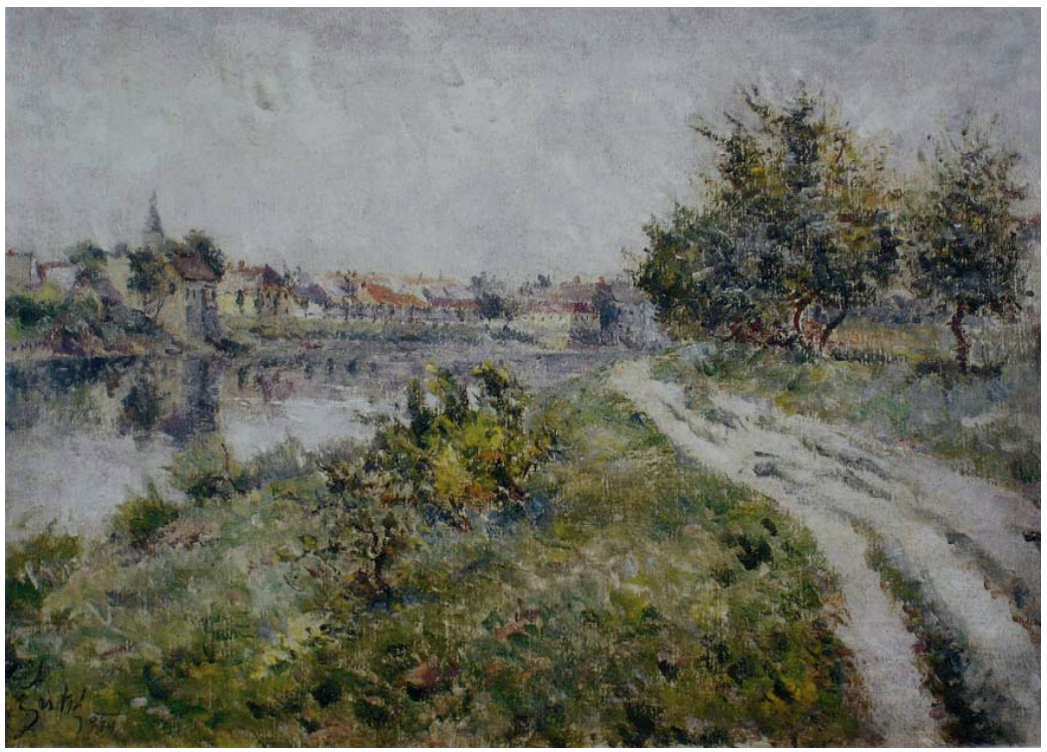

Ljudevit Šestić, Banija i gaza, ulje na platnu, 1944. 
autentičnog hrvatskog impresionizma" (Peić 1969: 203), znao naslikati zrak sjevernohrvatskog (riječnog) pejsaža. Stoga je sasvim prirodno da je prostor njegove slike ispunjen ugođajem/ozračjem, ,ponajviše treperenjem zraka koji zamagljuje obrise i sve je dano u mrljama, kromatskim krpicama" (Albaneže 2005: 18). On, kao i Matoš $U$ travi, gradi sliku u dugačkoj perspektivi: od prašnjavog puta, staze u prvom planu, preko kuća, tornja pa sve do neba gdje „bijeli oblak snijeva” u trećem planu slike.

Kod obojice čitamo kolorističku perspektivu, tople su boje u prednjem planu. Matoš u početnoj dionici pjesme ima motive prašnjavog puta, žutog cvijeća, žita, a iste ili slične motive neizostavno nalazimo u Šestićevim pejsažima. Posebno je zanimljivo kako se u njima relativno rijetko pojavljuju ljudi, a kad se pojavljuju, onda je riječ o, kako bi Albaneže rekao, ,štafažnoj figuraciji” (Albaneže 2005: 10), figurama koje se skicoznom spontanošću potpuno utapaju/uklapaju u atmosferu, u opći ton slike. Šestić slika ,prima vista", na prvu loptu, hvata trenutačne ugođaje, brzopotezno ih bilježi te ostvaruje učinak prozračnosti konkretnog motiva. Prema njemu je nesentimentalan, kod njega nema simboličkih implikacija, ekspresionističkih akcenata, izmišljanja, literariziranja. On želi biti primjer, kako je Pissarro govorio, „slikarskog slikarstva”, on je „kolorist lakokrilnog trenutka”, matoševski rečeno.

Dakle, uzevši u obzir samo navedene elemente impresionističke poetike po načelu pars pro toto, možemo reći da intermedijalna korespondencija između A.G. Matoša i Lj. Šestića postoji ne samo na površinskoj strukturi, nego i u samoj dubinskoj strukturi gradnje slike/pjesme.

\section{4. (Ne)zaključna misao}

Kulturološko čitanje trojice umjetnika riječi i slike, rođenih u Slavoniji, obogaćuje hrvatski kulturni krajolik u regionalnom, nacionalnom (Leović, Šestić) i izvannacionalnom prostoru (A.G. Matoš). A Matošev lirski tekst, potentan i konzistentan, procijeđen kroz „mider” životnog i domovinskog iskustva, biva, jednostavno po sebi, zahvalan za različite nepregledne intermedijalne i intertekstualne korespondencije. Budući da je za Matošev postupak gradnje lirskog teksta, kako je to već primijetio V. Žmegač (1993), očigledna „slikovna organizacija pjesme”. Ako su slikari Šestić i Leović 
u ovome kratkom kulturološkom radu imalo potvrdili ovu Žmegačevu detekciju, onda i sâm rad dobiva svoj mali reison d'être.

\section{Literatura}

Albaneže N., 2005, Ljudevit Šestić. Ulja, crteži, akvareli, pasteli: 1913-1961, Zagreb.

Chevalier J., Gheerbrant A., 1989, Rječnik simbola, prev. A. Buljan et al., Zagreb.

Matoš A.G., 1973, Sabrana djela, sv. 5, Pjesme. Pečalba, ur. D. Tadijanović, Zagreb.

Milanja C., 2013, Postmoderna je ubila Boga, a ne Nietzsche, „Vijenac”, 30. svibnja, str. $4-5$.

Oraić Tolić D., 1980, Pejzaž u djelu A.G. Matoša, Zagreb.

Oraić Tolić D., 2013, Čitanje Matoša, Zagreb.

Peić M., 1969, Hrvatski slikari i kipari: Slavonija-Srijem, Osijek.

Šuvaković M., 2005, Pojmovnik suvremene umjetnosti, Zagreb.

Zec D., 2013, Josip Leović (1885-1963). Osječki slikar, grafičar i kipar, Osijek.

Žmegač V., 1993, Duh impresionizma i secesije, Zagreb. 